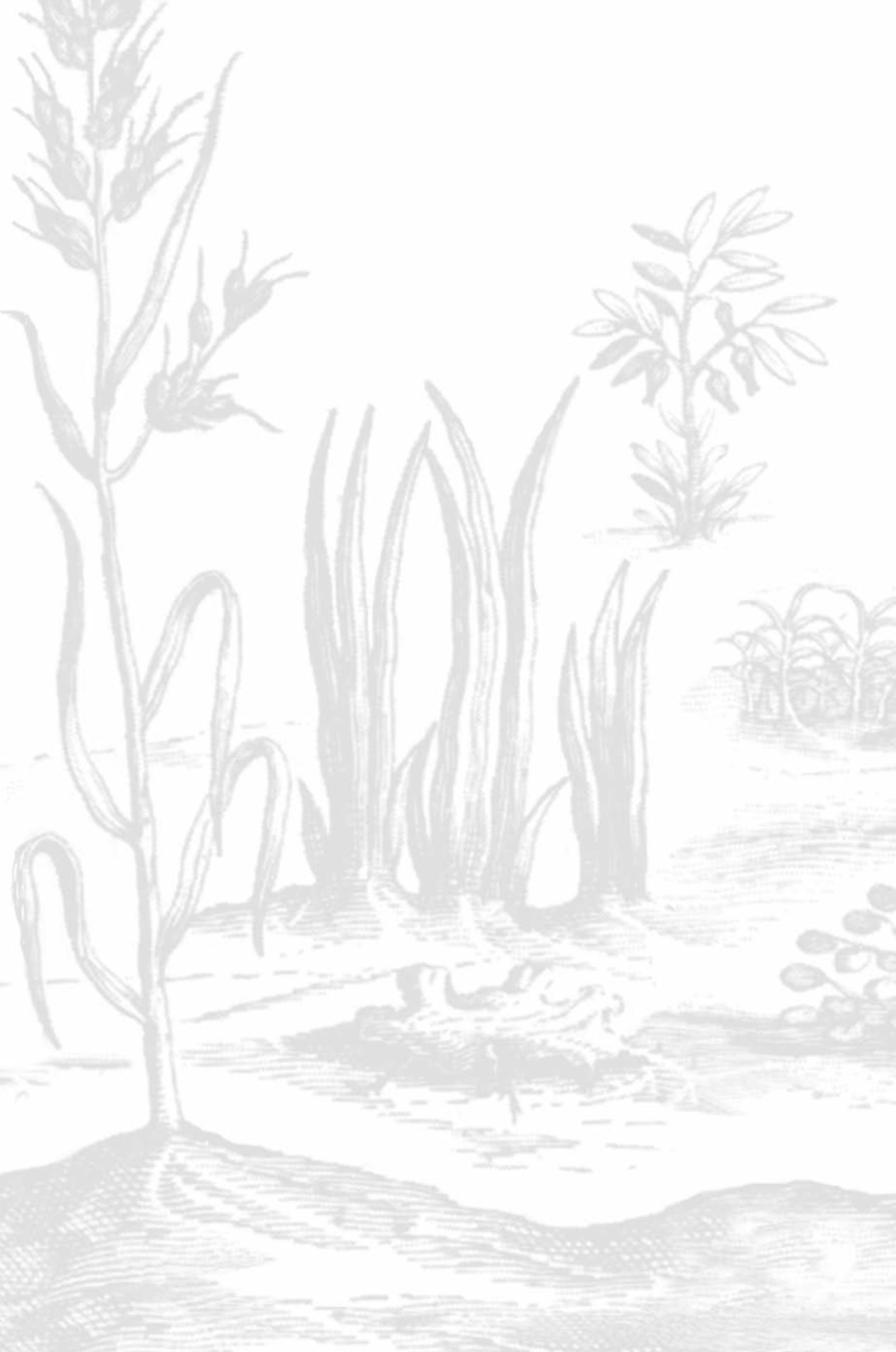




\title{
IN THE SHADOW OF SLAVERY
} Africa's Botanical Legacy in the Atlantic World

\author{
JUDITH A. CARNEY AND
}

RICHARD NICHOLAS ROSOMOFF

\section{田}

UNIVERSITY OF CALIFORNIA PRESS

BERKELY LOS ANGELES LONDON 
University of California Press, one of the most distinguished university presses in the United States, enriches lives around the world by advancing scholarship in the humanities, social sciences, and natural sciences. Its activities are supported by the UC Press Foundation and by philanthropic contributions from individuals and institutions. For more information, visit www.ucpress.edu.

University of California Press

Berkeley and Los Angeles, California

University of California Press, Ltd.

London, England

(C) 2009 by Judith A. Carney and Richard Nicholas

Rosomoff

Library of Congress Cataloging-in-Publication Data

Carney, Judith Ann.

In the shadow of slavery : Africa's botanical legacy in the Atlantic world / Judith A. Carney, Richard Nicholas

Rosomoff.

p. $\quad \mathrm{cm}$

Includes bibliographical references and index.

ISBN 978-0-520-25750-4 (cloth : alk. paper)

I. Blacks-Ethnobotany-America-History.

2. Blacks-Ethnobotany-Africa-History.

3. Slaves-America-History. 4. EthnobotanyAmerica-History. 5. Ethnobotany-Africa-History. 6. Plants, Edible-America-History. 7. Plants, Edible-Africa-History. 8. Medicinal plantsAmerica-History. 9. Medicinal plants-AfricaHistory. Iо. America-Civilization-African influences

I. Rosomoff, Richard Nicholas, I956- II. Title.

E29. N3C 382009

$581.6^{\prime} 3097-\mathrm{dc2} 2$

2009015360

Manufactured in the United States of America

I9 $\begin{array}{llllllll}\text { I } 8 & \text { I7 } & \text { I6 } & \text { I5 } & \text { I4 } & \text { I } 3 & \text { I } 2 & \text { II }\end{array}$

$\begin{array}{llllllllll}10 & 9 & 8 & 7 & 6 & 5 & 4 & 3 & 2 & \text { I }\end{array}$

This book is printed on Cascades Enviro I ००, a I ००\% post consumer waste, recycled, de-inked fiber. FSC recycled certified and processed chlorine free. It is acid free, Ecologo certified, and manufactured by BioGas energy. 
For Elaine Rosomoff

and in loving memory of Margaret G. Carney,

Louis J. Carney, and Hubert Rosomoff 
